\title{
Soil is Life and the Importance of Asking Questions
}

\section{Hague $A^{*}$}

CellSonic: Manufacturers of Medical Equipment, United Kingdom

*Corresponding author: Andrew Hague, President, CellSonic: Manufacturers of Medical Equipment, United Kingdom, Tel: +1 315210 6307; Email: cellsonic.beauty@gmail.com

\section{Short Communication}

Volume 3 Issue 5

Received Date: September 10, 2019

Published Date: October 14, 2019

DOI: $10.23880 /$ eoij-16000217

\section{Abstract}

Life on land depends on soil. From it grow plants that feed animals. If the soil is impoverished then so is food and health suffers.

\section{Questions}

We all ask questions. Usually it is, "Does he/she love me?" or "When will the rains come?" Every day I enjoy struggling with, "If I could only have one bicycle, which would it be?" (answer, Brompton-Rohloff) A question that defeats most economists although I answered it years ago is, "What is a country's most valuable asset?" Answer, soil.

\section{Soil is an Asset}

Soil allows habitation and life for all animals. A country may have minerals to extract such as iron ore or a community of financial wizards but these do not support life without first having a food supply upon which further economic activity can grow. For example, Switzerland's GDP includes a large sum for financial trading. This is neither permanent nor committed to its location. Laws passed in America are affecting bankers' behaviour in Switzerland. There will always be the alpine meadows able to nourish a population albeit not as large as one that is currently able to import foods paid for by exported services. Norway's resources include fish, wood, oil and timber. The oil has bestowed economic benefits in recent years and the wise government never expected the market to last forever so it now has the world's largest sovereign investment fund. Fish from the sea combines with locally grown foods to support the people. Ireland, by contrast, historically never exploited its fishing opportunities and relied mostly on the land. When hit by the potato blight, the prospect of starvation drove many to emigrate. Today, the soil remains important. Political disruption by Britain, its main trading partner, remains a threat to their livelihood and their own local produce will still be there come what may. The same cannot be said for countries in the Middle East dependent on oil and financial services. If their sales cease, their land is unable to support more than a few camel herders and pearl divers as it used to be before oil was discovered. They have very little soil.

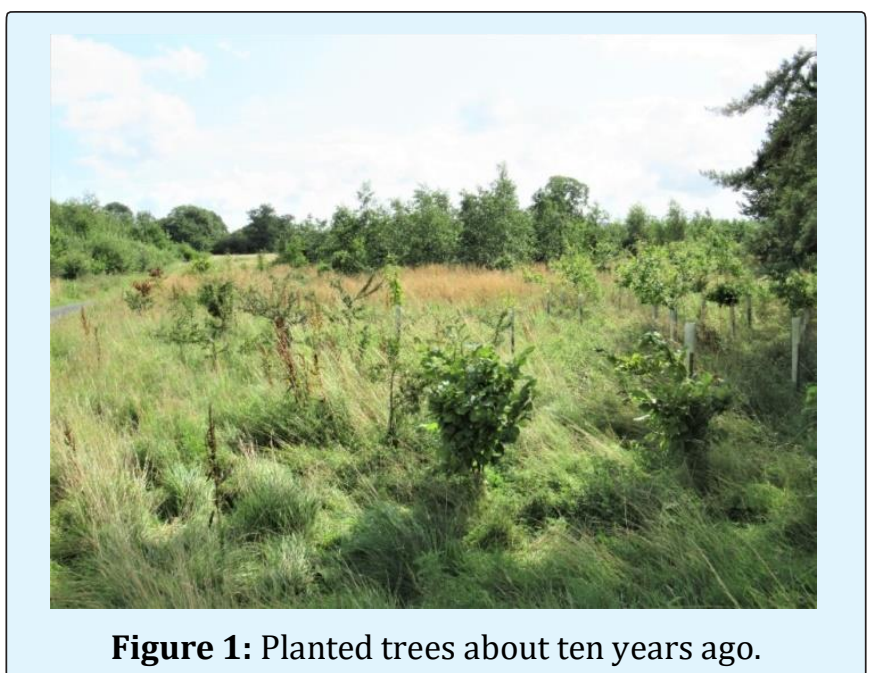

The photo above in England shows land that was planted with trees about ten years ago. In the foreground the trees are still small compared to those in the background. The soil in the foreground is inferior as this was alongside a railway line, now disused, to the right and 
out of the picture. Beyond, where the trees have grown taller, the land had always been cultivated and manured for many years, maybe centuries.

\section{Irrigation}

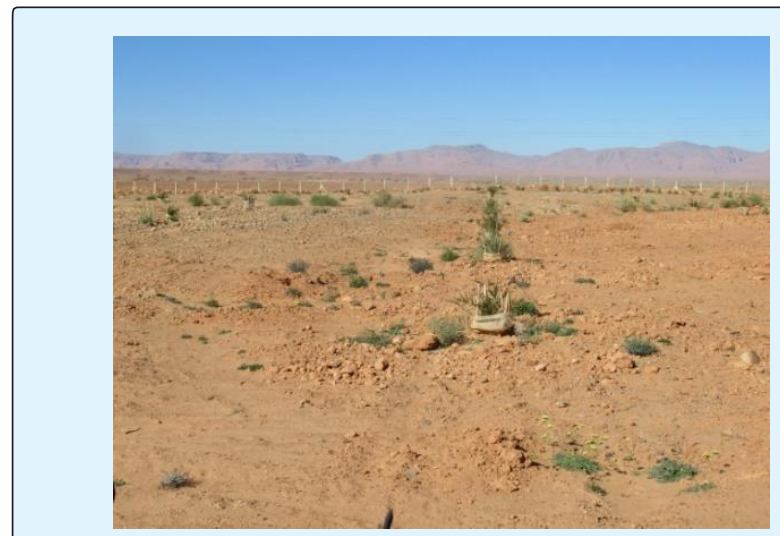

Figure 2: Bared land surface in south of Morocco, north of the Sahara.

The photo above is near Errachidia in the south of Morocco, north of the Sahara. It hardly ever rains here. Without water, soil is not active. A few plants are growing but the land surface is naturally bare. Forwards from the camera runs a row of newly planted madjool date palms [1].

Water is pumped from underground (the aquifer) into a reservoir on the date farm shown in the photo below. On the far left are the solar panels powering the pumps. The government of Morocco helps to finance these farms to bring employment to a neglected region and provide exports. There is a vast market for high quality dates.

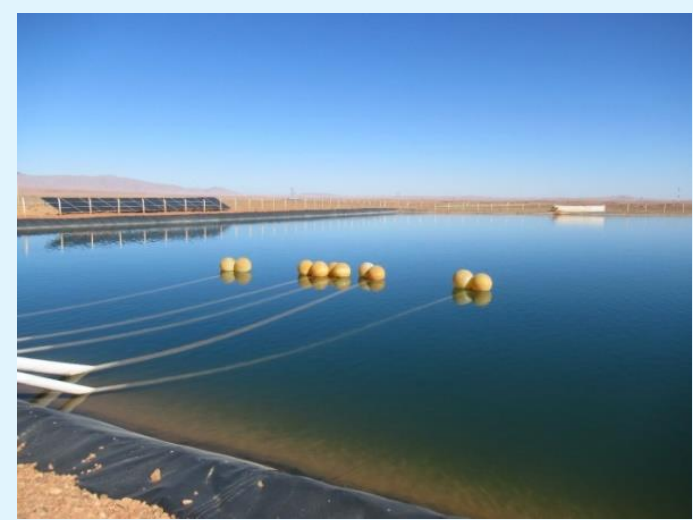

Figure 3: Pumped water from aquifer into reservoir.

Hague A. Soil is Life and the Importance of Asking Questions. Ergonomics Int J 2019, 3(5): 000217.

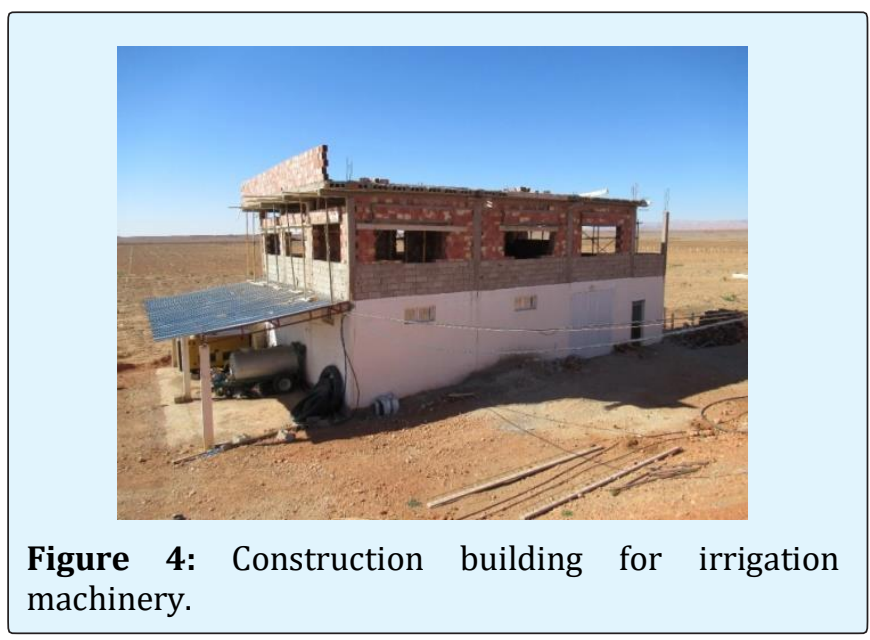

The farmer is constructing a building for the irrigation machinery that includes adding nutrients to the water in carefully calculated doses.

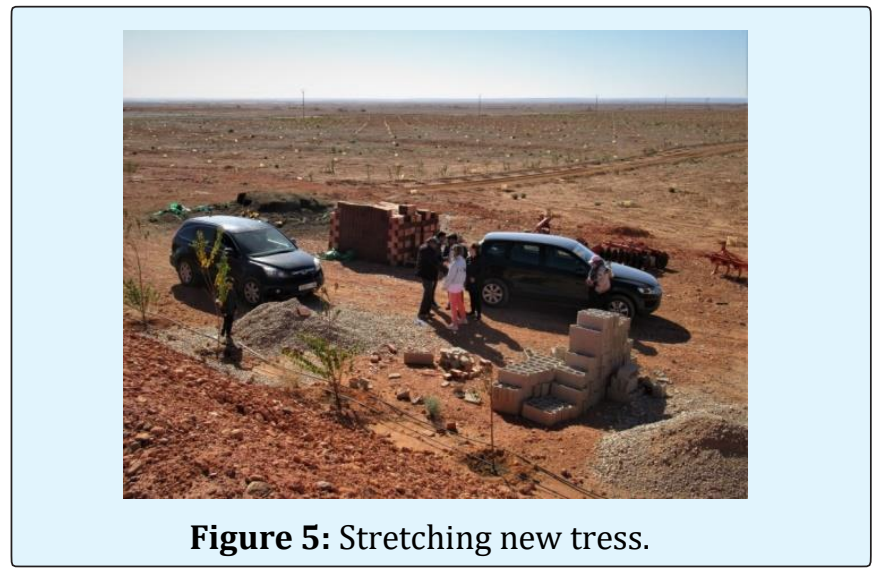

In the photo above, beyond the cars are rows of new trees stretching into the distance. In the foreground are pipes carrying water from the irrigation building. Behind the camera is the reservoir.

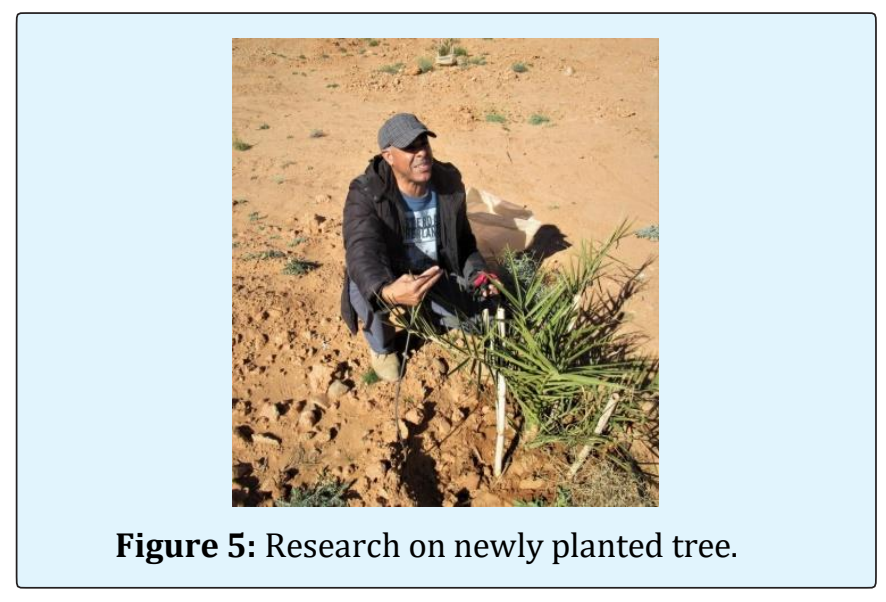

Figure 5: Research on newly planted tree. 


\section{Ergonomics International Journal}

Here the farmer is kneeling beside a newly planted tree. In his right hand is an irrigation pipe with a tapered end that is inserted into the soil close to the roots of the tree. Notice that the pipe is thinner than an electrical cable. Every tree on this vast farm is fed by a permanently fitted irrigation pipe the same as shown here. Water is the scarce resource that is carefully managed to deliver enough nutrients to the tree without any wastage. The process is called drip feeding. By the third year, harvesting dates will start.

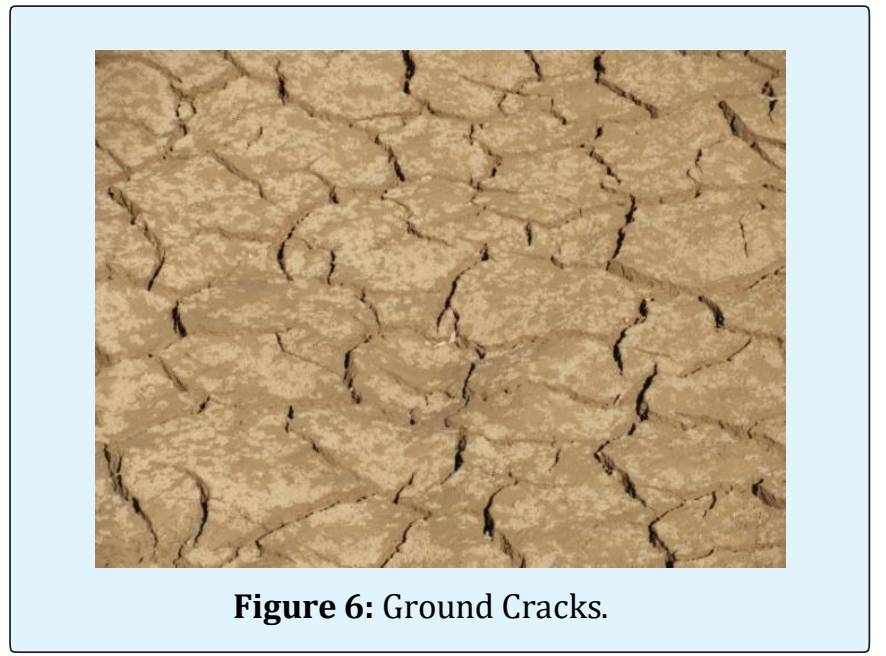

Where there has been surface water that has evaporated the ground cracks. Should any plants have started to grow here, their roots are torn by the cracks opening up and releasing moisture from below. Soil and plants need a constant supply of water.

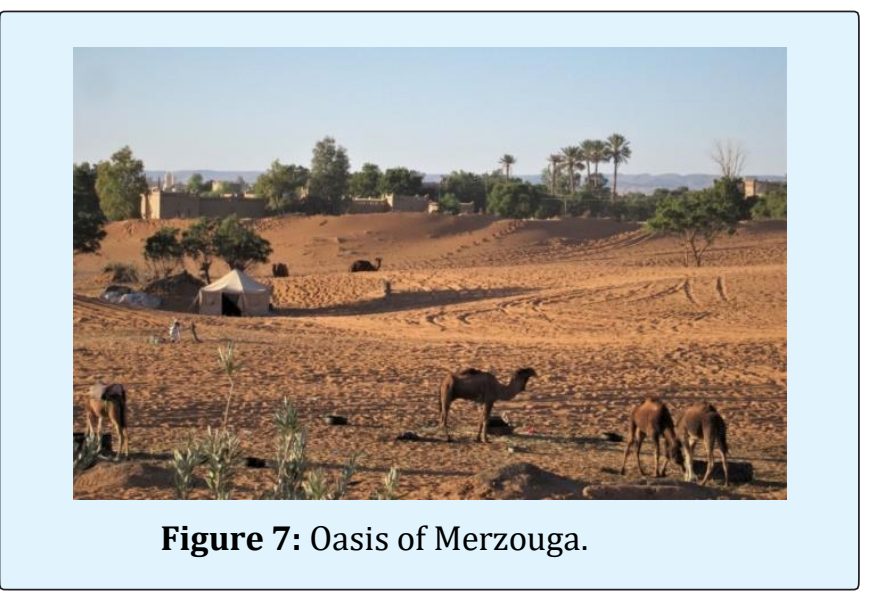

Settlements are only possible where there is water. Here is the oasis of Merzouga on the fringe of the Sahara. The water is underground.
The photo below is 180 degrees to photo above with the dunes of the Sahara stretching south into Africa. No water means no soil means no plants mean no life.

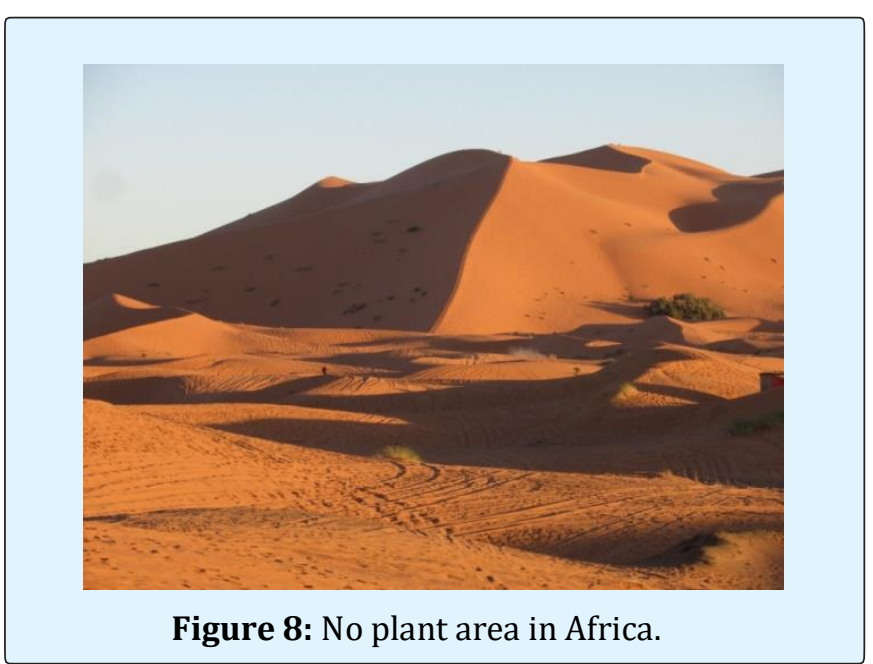

\section{Managing Soil}

An excellent explanation of soil is at https://en.wikipedia.org/wiki/Soil

It tells you everything about soil except how to grow better tomatoes. That omission will be deliberate. Managing soil is a different subject. Trying to get more and better plants to grow has been our quest for centuries. There is an understanding that soil is a finite resource; there is a limit to what it can support. If too much is taken out, something has to be put back. Leaving land fallow is an old method. Adding fertiliser is more recent. The biochemical process within soil is accepted as fundamental to our food supply. If we harm it, we suffer.

There are two parts to soil; alive and innate. The living constituents are mostly bacteria. The innate parts are minerals which form nutrients taken up by plants. The transfer of nutrients into plants requires helpful bacteria. Some of the life in soil is bigger than bacteria. It is said, or I was once told, that there is more meat under the surface of a field on which cattle are grazing than there is on the surface. In other words, the worms amount to more than the cattle. It is also said, that we should consider eating worms.

Adding fertilizers seems not to be working. Crop yields are increasing as shown by weight and volume but when the nutritional value of the food is measured, the food is getting worse. This deterioration is widely reported in the USA where large scale farming predominates. Medical 


\section{Ergonomics International Journal}

colleagues explain it to me like this: When Popeye ate spinach to boost his strength to go to rescue Olive Oyl, gulping down one tin was enough. The cartoon films actually increased spinach consumption in America by a third.

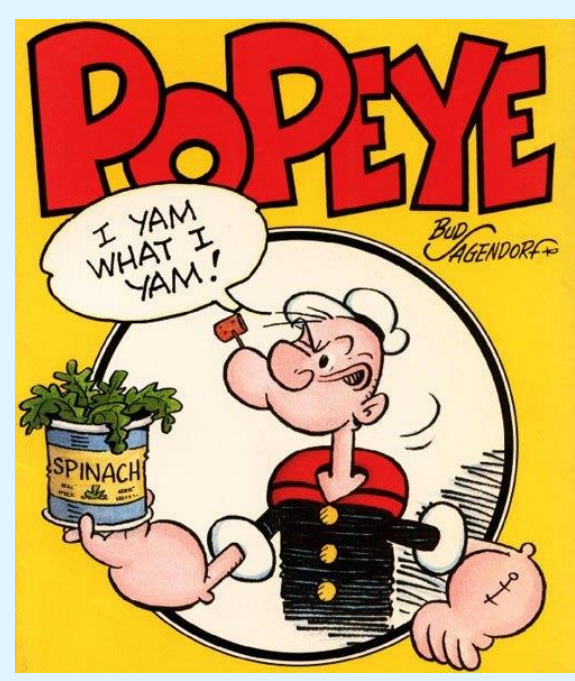

Figure 9: Popeye.

\section{Nutritious Food}

Although the fact that the claims made for the iron content of spinach in the 1920s and 30s were exaggerated, it is nevertheless true that to get as much iron today as Popeye would have had almost a hundred years ago, one would need ten tins of spinach, not one [2]. This depletion of nutrients is not confined to spinach. All the food conscious doctors in America report that a major cause of ill health, of what brings patients to them, is inadequate food [3]. The quantity of food is there; it is what is not in the food that is the problem. All the advice about what to eat fails when the recommended fruit and vegetables are little more than fibre and water. They look good in the supermarket but are useless in the stomach.

\section{Plant Food}

My earlier papers on health, exercise and diet led me by chance to a company selling a plant food $[4,5]$. I am neither a gardener nor a cook but as a cyclist, I like and need food, hence the interest [6]. The message from Batmaster made sense so I asked questions. They source their plant food from huge caves in which bats live with their droppings accumulating over the years. The guano is dry and odourless. Add water and it can be sprayed on the crops. They found that they have to use spring water. Tap water did not work. Somehow it fails to bring the bacteria back to life. Is it the chlorine in the tap water? Is that something else to worry about? Using spring water, the Batmaster product produces better plants. The verdict of the growers, predominantly gardeners who eat what they grow, is that this is improving the soil allowing the plants to grow naturally. They taste better and the gardeners seem happy digging in next year's crop. They also calculate that they are saving money. Gross up to what a farmer should apply to large fields and compare it to what they are paying for chemical fertilizers and the Batmaster is the best buy; cost down, quality up.

The idea of using manure is ancient. It recycles the crops eaten by foraging animals. Bat guano is different because it is not putting back on the field that which grew on the field; it is introducing new bacteria. This new life invigorates the soil. Bacteria transport the minerals in the soil to the roots. Bats eat fruit and insects. They are selective, not chomping along devouring everything in their path including grass already contaminated with their own droppings. Like eating worms, some advanced thinkers say we can eat insects. That may be so. I am ready to let the bats do it. My assessment is simple; if enough people confirm that Batmaster produces better food, I am satisfied. How it does it is for others to work out. The health of people is my concern. To know that only spring water can be used to activate the Batmaster is an assurance that the bacteria are sensitive. Use tap water and the Batmaster is useless. Bacteria are the vital ingredient.

\section{Diabetes}

Obesity and diabetes are a plague. During the war when there was food rationing, these diseases were not reported. The cause is over eating and under exercising. But why are they over eating? Is their food not satisfying them? Are they driven to want more because something is lacking? Is it like Popeye's spinach that does not have the nutrients it used to have? If their food was good, would they then have the urge to skip and jump?

\section{Food in the Shops}

Having found how to grow better crops, the next step is to persuade the shops to sell them. Outwardly the vegetables look the same. The weight and appearance are what the trade buyers and the customers in the shops go by. There is no opportunity to cook the food and then somehow test if you can cycle faster and further on the better food. We trust the shops, especially the big 


\section{Ergonomics International Journal}

supermarkets, because we assume they employ science graduates with agriculture degrees who know good food from bad. It looks as though our trust is misplaced. The best food is to be found in local markets laid on temporary stalls and served by the person who dug it out of the ground that morning. This we call organic and it costs more than the shiny stuff in the smart shops and supply is unable to meet demand. Given that customers understand that food is only as good as the soil in which it grew and they want the best, it is strange that farmers who follow the money more than most do not switch to natural plant foods such as Batmaster to reduce their costs and increase their sales. The industrial chemical giants are pushing the synthetic fertilizers and confusing the farmers.

\section{Ask a Scientist}

The same confusion, corruption many say, is seen with medicine where Big Pharma dominates and only pharmaceuticals are allowed. Doctors who fail to think for themselves are as guilty and ignorant as farmers and retailers who accept that the man in a suit knows best. Science is only as good as the integrity of the researchers. Few university studies are done without payment from companies who want to make the evidence fit the publicity. Science has become corrupt. Dr Haltiwanger has said that the best thing Americans can do for their own health is to grow their own food in their own back yards.

Batmaster is run by a lady who used to work in the fertilizer business for an international giant. She has all the scientific qualifications. Like Haltiwanger on the medical side, she increasingly became disillusioned with the methods of her employer and had the courage to set up on her own. The bureaucracy supporting the regulations about what can be added to soil look even more daunting than what determines what can be injected into our bodies. The idea that these regulations protect us is nonsense; they are harming us. The blame must be directed at politicians for it is they who make the laws. They are advised by the experts who come from the big companies who are under shareholder pressure to pay dividends. It is not a system designed to do what is best for the people. Even politicians need nutritious food and a cure for cancer. Maybe this article will help some to start questioning and thinking.

\section{Cancer}

The question I am often asked is how to avoid cancer or, put another way, does poor food cause cancer? Yes, poor food can lead to cancer. The explanation is complex.
Normally and healthily, our body cells replace themselves about every six weeks. There are billions of cells and the chances of a new cell not being the same as the cell it replaces are high. Often the new cell is not the same as its predecessor, it is a mutation and that is what cancer is. We all get cancer every day. To cope with this, we have an immune system. It gives us immunity to health problems. The immune system combats a cold, fights infection in a wound and stops the cancer. It converts a mutant cell to normal (benign) or kills it. The result is that we go on from day to day without cancer growing. The immune system caught it before it could spread.

If the immune system had been weak it would have failed to intercept the cancer. Therefore, it is essential to support the immune system. This requires good food, exercise, a content state of mind and no too much going wrong all at the same time.

The immune system has priorities and a threshold. Its priorities are to tackle the most threatening problem first and leave less dangerous conditions to later. Mutant cells are extremely dangerous so, we hope, they will be dealt with before other problems such as a cold and a runny nose. The threshold is a limitation that also applies to other organs. When the work load on the immune system exceeds a limit, goes above the threshold, it completely stops. It does not just deal with the most dangerous problem; it deals with nothing. The body then has no protection.

The medical establishment's way to deal with cancer for decades has been to apply chemotherapy. This kills cells, good and bad, and shuts down the immune system. It removes all the body's ability to recover and kills good cells in the hope of saving the person by killing the cancer cells. It is the most ridiculous strategy imaginable based, when you investigate chemo and the suppliers, on profiting from desperation and ignorance. Where and when there have been better ways to combat cancer without side effects, Big Pharma always uses its influence to kill off the competition. Cancer is the biggest scam the world has ever seen. Look at all the charities begging for your money for research that never produces a cure.

Eat and live well to keep the immune system working and the chances of cancer are minimized. Smoking is a known cause of cancer. Fill the lungs with tar and they cease to work. The immune system will abandon its duty. Drink alcohol regularly and you overload the immune system. Combine the alcohol with poor food and the immune overload kicks in allowing mutant cells to 


\section{Ergonomics International Journal}

multiply unhindered. Thus, there is a link between poor food and cancer and wrong behavior and cancer.

Many doctors, disillusioned by established procedures of chemotherapy and radiation, have set up clinics based on nutritious foods and responsible life style. It is often called integrative medicine. Most of these doctors have graduated from medical school the same as all the doctors in the big hospitals but the break-away group has decided that all the side effects and suffering are wrong. They asked the questions. In some cases, a carefully programmed nutritious diet, often with food grown in their own gardens, has cured the patient of cancer [7]. They have supported the immune system and the body's own built-in repair system has been able to make a cure. Unfortunately, many patients are too ill by the time they realise they are being exploited at the big hospital and decide to seek a better way. That is where my company, CellSonic, comes in.

All cancers have in common an electrical potential of 15 millivolts from the centre of the cell to outside the membrane of the cell. This compares to - 70 millivolts for healthy cells. Cancer is an electrical fault. It is not a disease. To correct it, use non-surgical, irreversible electroporation. That is what CellSonic does. Drugs are not needed and are useless; they can prevent the cells responding to the electro-magnetic field [8-10].

There are three stages in the cure of cancer:

1. Stop the cancer

2. Repair the damage caused by cancer.

3. Find out what allowed the cancer to start in the first place.

CellSonic will stop the cancer. Repairing the damage requires the right foods, not too much, and time. Let the immune system start up again. Whilst this is going on and it can take week and months, get to know the patient and learn about their earlier life style. Sometimes cancer is bad luck but often there will have been excesses, usually stress, where the cancer was not defeated and it spread. To the question of what is the main cause of cancer, I sometimes reply, "Divorce" and wait for the response. It may have been ten years before but the stress remained. It may have been the daughter's divorce and her elderly father was more upset than she was and he was unable to fight off cancer. Keeping the mind relaxed can be stressful!
Blame our bodies for the cell replacement system. It allows mutations. We got our brains by the experimental process of mutation. If we had stayed as we were, we would never have become homosapiens. What gave us our brains also gave us our weaknesses and we have to use our brains to overcome the disadvantages.

Growing crops on soils stripped of bacteria and nutrients is not clever. It leads to a chain of problems. Get the start of that chain right and the other links in the chain can then be right but start wrong and the whole assembly is wrong. We depend on good soil.

\section{References}

1. Annie Price (2015) Medjool Dates: The Healthiest Natural Sweetener?

2. The True Science of Spinach and What the Popeye Mythology teach us about how error spreads. Brain Pickings.

3. Steve Haltiwanger (2017) Clinical experience with use of nutrition in hospitals. The Electric Human: Section-2-Physics \& Physiology.

4. Andrew Hague (2018) The ins and outs of elimination. Lupine Online Journal of Medical Sciences 1(3).

5. Andrew Hague (2018) The Exercise Continuum and the Role of Doctors. OAJ Gerontol \& Geriatric Med $3(5)$.

6. BatMaster.

7. https://imc.wroc.pl/

8. Andrew Hague (2019) Cancer-The Ultimate Plan. Acta Scientific Cancer Biology 3(3): 67-69.

9. Andrew H (2019) Cancer and Wounds are Similar. Nov Appro in Can Study 2(4): 543.

10. Andrew Hague (2019) Cancer and Wounds are Similar. Acta Scientific Cancer Biology 3(6): 25-30. 